\title{
The effects of women's satisfaction with their birth experience on breastfeeding sufficiency
}

\author{
Nilay Gökbulut ${ }^{1 \mathrm{a}}$, and Kerime Derya Beydağ ${ }^{2}$ \\ ${ }^{1}$ Msc. Midwife, Malatya Doğanşehir State Hospital, Malatya/Turkey \\ ${ }^{2}$ Faculty of Health Science, Department of Nursing, Okan University, Turkey
}

\begin{abstract}
Postpartum is the period when the family cares and creates a safe environment for the baby, communicates with the baby, adopts new roles, develops family awareness and copes with the problems of the baby. This study has been performed to define how the mothers assessed their birth experience and as a descriptive with intent to reveal the effects of this experience on the postnatal breastfeeding period. The sample of study was composed of 281 mothers who were in the postnatal clinic of İstanbul Okmeydanı Research and Training Hospital and agreed to participate the study between January-May 2015, literate and able to talk and understand Turkish, and also gave birth vaginally or by cesarean section. The survey form included the descriptive features of women and "The Scale Of Satisfaction" and The Scale of Breastfeeding Sufficiency" have been used for gathering data. SPSS 22.0 program was used to analyze the data. As a consequence, the mothers' satisfaction with their birth experience scale has been varied according to the delivery methods and the elapsed time after birth experience. Relatedly when the satisfaction level of them was varied, the breastfeeding sufficiency of them was also varied, too.
\end{abstract}

Keywords: Birth experience, Breastfeeding Suffiency, Satisfaction.

\section{Introduction}

Family is an indispensable, traditional and social institution of the society. In order to provide the continuance of humanity, raise conventionalized individuals, pass down from generation to generation; the family has a universal mission and responsibility. With fertility function, this universal mission is accomplished [1].

Postpartum is the period when the family cares and creates a safe environment for the baby, communicates with the baby, adopts new roles, develops family awareness and copes with the problems of the baby. This period may be either experienced as a very positive and satisfying period for the family that strengths the family bonds, or as a crisis period [2].

a Corresponding author: derya.beydag@okan.edu.tr 
In social lives of couples, changes appear when they have children. If mother is working, she may have to keep her business life in the background for a time. The time she spends at home will also increase. Consequently, limitations that occur in social and business life may lead the mother to get stressed. Besides, it is possible for many fathers to get stressed since the interest and love of their spouses completely turn towards the baby. The old order in previous bilateral relationship of spouses may go bad, expectations of spouses from each other may change, an increase in their duties and responsibilities may be observed [3].

In our country, mothers are often discharged from the hospital 24 hours after they give birth. In order to prevent some complications which may be urgent during the first 24 hours, this period may be considered sufficient. However, this period may not be sufficient to support the mother to adapt herself for the new situation during postpartum period. In the first day after the birth, the care to be given from healthcare professionals as well as the family, particularly from delivery nurses/nurses, is very important for the mother to adapt herself for the postpartum period, who is intensively in contact with healthcare staff [4].

In order to allow the neonate to grow and develop healthy, he/she should have adequate and balanced nourishment during infancy. The properties which make breast milk the most suitable nutrient are that it changes according to neonate's requirements, has preventive property against infections, can meet the baby's physiological and psychosocial requirements by itself during the first 4-6 months, and is economic. During the first 4-6 months, it is recommended not to give even water in addition to breast milk and after 4-6 months, that breast milk should be continued with additional nutrition support until the baby is one year old [5].

Hospitals are suitable environments to provide training for the mother during prenatal and early postnatal periods. Following that; delivery nurses, nurses and physicians who were in charge during the first step have the most important part. They should be aware of the factors which may cause to leave breastfeeding in early period, and perform the required applications both during prenatal and postnatal periods to prevent those. Delivery nurses/nurses should give right and satisfactory information to mothers about self-care requirements and baby caring, and make sure that they understood those issues [6].

With this study, it was both intended to review from where birth experiences of mothers and breastfeeding self-sufficiencies are affected, and whether there is a relationship or not between birth experience and breastfeeding self-sufficiency.

\section{Method}

This study was conducted as descriptive in order to determine the effect of women's' satisfaction from birth to breastfeeding self-sufficiency, identify the factors which affect the satisfaction from birth experience and breastfeeding self-sufficiency

\subsection{Participants}

Population of the study consisted of puerperants who were registered in T.R. Ministry of Health Istanbul Okmeydanı Training and Research Hospital in $2014(\mathrm{~N}=3043)$. Sample of the study consisted of 281 women who were identified by sampling formula with a known population, by considering the number of puerperants in 2014 in the abovementioned hospital. 


\subsection{Procedure}

With regard to compatibility of the study with ethical principles, permission was taken from Aluş Tokat who created the Postpartum Breastfeeding Self-Sufficiency Scale and from Taşçı who created the scale of Satisfaction from Birth Experience. Before collecting data, ethics committee approval was obtained by applying to Ethics Committee of T.R. Okan University, then permission was taken from Beyoğlu Association of Public Hospitals which T.R. Ministry of Health Istanbul Okmeydanı Training and Research Hospital is a member of. All participants were informed about the aim of the study, eagerness and willingness to participation was cared and written consents were taken from all mothers participating the study.

Data were obtained from questionnaire form which includes the defining characteristics, and from "Satisfaction of Women from Birth Experience Scale" and "Breastfeeding Selfsufficiency Scale". The questionnaire form that includes the defining characteristics of women consisted of 10 questions. Satisfaction of Women from Birth Experience is a scale which has in 4 point likert type with 10 questions [2]. The lowest point to be obtained in the test shall be calculated as 10 and the highest as 40. As the points increase, level of satisfaction is interpreted as low. Breastfeeding Self-sufficiency is a 14 question scale. The lowest point to be obtained in the test is 14 , while the highest is 70 . If the points are high, it is interpreted as the breastfeeding self-sufficiency is high as well. The scale is 5 point Likert type and evaluated as $1=$ not sure at all $5=$ =always sure.

In analyses of data SPSS 22.0 programme was used. In defining statistics; average, standard deviation, median, lowest and highest frequency and rate values were used. Distribution of variables was measured by Kolmogorov Simirnov test. In analysis of quantitative data, Kruskal-wallis, mann-whitney u test were used. In correlation analysis, spearman correlation analysis was used.

\section{Findings}

In Table 1, SFBES and PBSSS average points of mothers were calculated and presented. In our study, the average point was calculated as $21,5 \pm 5,2$ in SFBES we applied to mothers. In

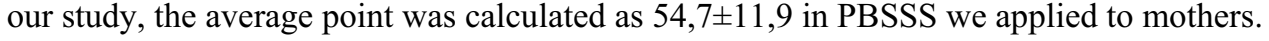

Table 1: Comparison of point averages between birth satisfaction of mothers scale and postpartum breastfeeding self-sufficiency scale $(\mathrm{n}=281)$

\begin{tabular}{|c|c|c|c|c|c|c|}
\hline \multirow[b]{2}{*}{$\begin{array}{l}\text { Satisfaction From Birth Experience } \\
\text { Scale }\end{array}$} & \multicolumn{2}{|c|}{ Min-Max } & \multirow{2}{*}{$\begin{array}{r}\text { Median } \\
21,0\end{array}$} & \multirow{2}{*}{$\begin{array}{l}\text { Av. } \\
21,5\end{array}$} & \multirow[t]{2}{*}{ \pm} & \multirow{2}{*}{$\begin{array}{l}\text { s.s. } \\
5,2\end{array}$} \\
\hline & 10 & 38 & & & & \\
\hline $\begin{array}{l}\text { Postpartum Breastfeeding Self- } \\
\text { Sufficiency Scale }\end{array}$ & 14 & 70 & 57,0 & 54,7 & & 1,9 \\
\hline
\end{tabular}

It was identified that there was a very weak and negative statistically significant relationship $(\mathrm{p}<0,05)$ between the SFBES point average and PBSSS averages of mothers $(\mathrm{rs}=-0,320)$ This result demonstrates that there is a negative relationship between satisfaction from birth experience and postpartum breastfeeding self-sufficiency (Table 2). 
Table 2: Correlation coefficients of satisfaction from birth experience scale and postpartum breastfeeding self-sufficiency scale $(\mathrm{n}=281)$

\begin{tabular}{llc}
\hline & $\begin{array}{l}\text { Postpartum Breastfeeding Self- } \\
\text { Sufficiency Scale }\end{array}$ \\
\cline { 2 - 3 } Satisfaction From Birth Experience & $\mathrm{R}$ & $-0,320$ \\
Scale & $\mathrm{P}$ & 0,000 \\
\hline
\end{tabular}

Spearman Correlation

As the time after the birth gets longer, satisfaction level of mothers from birth has significantly increased $(p<0,05)$. As the period after birth gets longer, since physical complaints reduce, adaptation to maternity increases and problems experienced during birth lose its freshness on the first day, it is considered that comfort and satisfaction will increase during postpartum. When the time that mothers gave birth and SFBES point average were observed, SFBES point average of the mother who gave birth before 0-30 days was identified as $54,8 \pm 12,1$ and SFBES score did not present a significant difference according to time elapsed after birth $(\mathrm{p}>0,05)$ (Table 3$)$.

Table 3: Comparison of point averages of satisfaction from birth experience scale and postpartum breastfeeding self-sufficiency scale according to how long ago the mothers gave birth $(\mathrm{n}=281)$

\begin{tabular}{|c|c|c|c|c|c|c|c|c|}
\hline & & Mir & & Median & Av. & \pm & s.s. & $\mathbf{P}$ \\
\hline $\begin{array}{l}\text { Satisfaction F } \\
\text { Experience Sc }\end{array}$ & Birth & & & & & & & \\
\hline & 0-30 Days & 10 & 38 & 21 & 21,6 & & 5,2 & \\
\hline How long ago & 31-60 Days & 19 & 32 & 25 & 24,4 & & 4,0 & 0016 \\
\hline birth? & $\begin{array}{l}\text { More than } 61 \\
\text { Days }\end{array}$ & 13 & 32 & 19 & 19,9 & & 4,9 & 0,010 \\
\hline $\begin{array}{l}\text { Postpartum B } \\
\text { Sufficiency Sc }\end{array}$ & stfeeding Self- & & & & & & & \\
\hline & 0-30 Days & 14 & 70 & 57 & 54,8 & & 12,1 & \\
\hline $\begin{array}{l}\text { How long ago } \\
\text { did you give }\end{array}$ & 31-60 Days & 29 & 70 & 45 & 46,6 & & 14,7 & 0.107 \\
\hline birth? & $\begin{array}{l}\text { More than } 61 \\
\text { Days }\end{array}$ & 40 & 70 & 55 & 56,6 & & 8,2 & \\
\hline
\end{tabular}

Kruskal-wallis

SFBES score did not demonstrate a significant difference between the mothers who have given birth once and more than once $(p>0,05)$. When number of times they gave birth and PBSSS point averages are compared, PBSSS score is found significantly higher for the ones who gave more than one birth than the ones who gave one birth $(p<0,05)$ (Table 4$)$.

According to breastfeeding of the previous baby, SFBES score did not demonstrate a significant difference $(p>0,05)$. When mothers' state in breastfeeding of their previous babies and PBSSS point average are compared, PBSSS average point was found higher for the ones who breastfed their previous baby and PBSSS score demonstrated significant difference between the mothers who breastfed their previous baby and the mothers having the first baby $(\mathrm{p}<0,05)$ (Table 5). 
Table 4: Comparison of point averages of satisfaction from birth experience scale and postpartum breastfeeding self-sufficiency scale according to how many times did the mothers give birth $(n=281)$

\begin{tabular}{llllllll}
\hline & & Min-Max & Median & Av. & \pm & s.s. & P \\
\cline { 3 - 8 } $\begin{array}{l}\text { Satisfaction From } \\
\text { Experience Scale }\end{array}$ & Birth & & & & & & \\
$\begin{array}{l}\text { How many Once } \\
\text { times did you Two or More } \\
\text { give birth? }\end{array}$ & 12 & 37 & 20 & 21,2 & 5,2 & \\
\hline $\begin{array}{l}\text { Postpartum Breastfeeding } \\
\text { Self-Sufficiency Scale }\end{array}$ & 38 & 21 & 21,7 & 5,2 & 0,357 \\
$\begin{array}{l}\text { How many Once } \\
\text { times did you Two Or More } \\
\text { give birth? }\end{array}$ & 14 & 70 & 54 & 52,9 & 11,0 & \\
\hline
\end{tabular}

Mann-whitney $u$ test

Table 5: Comparison of point averages of satisfaction from birth experience scale and postpartum breastfeeding self-sufficiency scale according to mothers' state in breastfeeding of their previous babies $(\mathrm{n}=281)$

\section{Satisfaction From Birth}

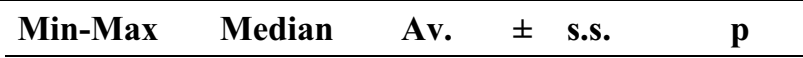

Experience Scale

\begin{tabular}{llllllll}
$\begin{array}{l}\text { Did you } \\
\text { breastfeed your } \\
\text { previous }\end{array}$ & $\begin{array}{l}\text { The First } \\
\text { Baby }\end{array}$ & 12 & 37 & 20 & 21,0 & 4,8 & \\
babies? & Yes & 10 & 38 & 21 & 21,9 & 5,4 & 0,430 \\
\hline No & 14 & 32 & 21 & 21,0 & 5,1 & \\
\hline
\end{tabular}

Postpartum Breastfeeding Self-

Sufficiency Scale

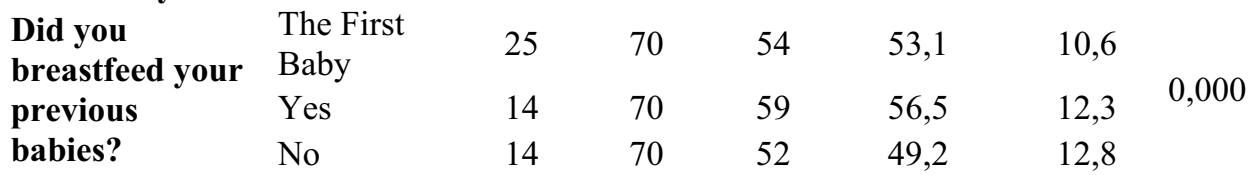

Kruskal-wallis ( Mann-whitney u test)

\section{Discussion}

In Table 1, 'de SFBES point average of mothers was calculated as $21,5 \pm 5,2$. In the study of Taşc1 (2005), SFBES point average was calculated as $21,8 \pm 4,3$. SFBES point average was found in parallel to study finding [2]. PBSSS point average was calculated as $54,7 \pm 11,9$. In the study of [6]. PBSSS point average of mothers was calculated as 59,49 $\pm 8,46$ while $55,88 \pm 10,85$ according to study of Dennis (2003) and $60,09 \pm 8,2$ according to study of Tokat (2009) [6-8]. PBSSS point averages were found parallel to study finding of Dennis (2003) while lower than study findings of Yenal et al. (2013) and Tokat (2009) [6-8]. It is considered that the reason why the study finding was found lower than the other study findings is the group which research was made on was selected from different regions.

In Table 2, SFBES averages of mothers according to their PBSSS points were evaluated with correlation aanalysis. It was identified that there was a very weak and negative statistically significant relationship $(\mathrm{p}<0,05)$ between SFBES point averages and PBSSS averages of mothers $(\mathrm{rs}=-0,320)$. This result reveals that there is a negatively 
relationship between satisfaction from birth experience and breastfeeding self-sufficiency. Before the study, a positive relationship was expected between birth experience and breastfeeding self-sufficiency. It is considered that the result might have occured since sample group did not show homogeneous didtribution and the mothers who participated the study consisted of people having different age groups and birth experience. Mother-baby interaction is an important factor that affects breastfeeding. The immediate start of motherbaby interaction in normal birth has an advantage on cesarean section. $56 \%$ of mothers who participted our study gave birth by cesarean section. Although the mothers who give birth by cesarean section do not feel pain during birth and pleased with the birth, when births take place by cesarean section; it may negatively affect the factors such as mother-baby interaction, the first breastfeeding period, stimulation of milk release; causes delay, and makes breastfeeding difficult, and this may reduce the mother's feeling of adequacy. Moreover, the reason of labor for mothers who give normal birth is that oxytocia increases uterus contractions. Increase in uterus contractions lead to mothers have child-birth pains, and reduce their satisfaction from birth. In the meantime, increase in oxytocia also raises the amount of prolactin and causes increase in milk release from breasts. Increase in milk release is considered as the mothers can breastfeed their babies easier and thus lead to increase in their level of satisfaction.

In Table 3, Wien how long ago the mothers in the study gave birth and their SFBES and PBSSS point averages are compared; it is observed that the time after birth gets longer, satisfaction level of mothers from birth significantly increases $(p<0,05)$. As the time after the birth gets longer; since physical complaints reduce, adaptation to motherhood increases and the problems experienced during birth lose their freshness on the first day; it is considered that comfort and satisfaction will increase during postpartum period. When the time that mothers gave birth and PBSSS point average were observed, PBSSS point average of the mother who gave birth before 0-30 days was identified as $54,8 \pm 12,1$ and PBSSS score did not present a significant difference according to time elapsed after birth $(\mathrm{p}>0,05)$. The reason for this was considered to arise from since majority of mothers in our study became willingly pregnant, this might lead to both increase in mother baby interaction psychologically and start the mother's breastfeeding of her baby earlier as well as provide the sustainability of breastfeeding.

In Table 4, when how many times the mothers gave birth and their SFBES point averages were compared, SFBES score did not reveal significant difference between the ones who gave one birth and who gave more than one birth $(\mathrm{p}<0,05)$. The mothers stated that they experienced the same pain regardless of times they gave birth. When their times of giving birth and PBSSS point averages were compared, PBSSS score is found significantly higher for the ones who gave more than one birth compared to ones who gave one birth $(\mathrm{p}<0,05)$. Breatfeeding self-sufficiency perception of mothers was evaluated who whether or not breasfeeding experience [9]. In the postnatal group, BSSP average of mothers having previous experience $(\mathrm{X}=62,9 \pm 6,6)$ was found higher than the ones having no experience $(\mathrm{X}=57.4 \pm 8.9)(\mathrm{t}=.-4.276, \mathrm{P}=0.00)$ [8]. This result had parallels with our study.

In Table 5, when SFBES point averages of mothers according to breastfeeding of their previous babies were compared, SFBES score did not reveal significant difference according to breastfeeding of previous baby $(p>0,05)$. When mothers' state in breastfeeding of their previous babies and PBSSS point average were compared, PBSSS average point was found higher for the ones who breastfed their previous baby and PBSSS score demonstrated significant difference between the mothers who breastfed their previous baby and the mothers having the first baby $(\mathrm{p}<0,05)$. The mothers who breastfed their previous baby can breastfeed their present baby more easily. 


\section{Conclusion and Suggestions}

Whether in the first step or delivery nurses, nurses and doctors working at hospitals have important responsibilities for being aware of the factors which may cause leaving the breastfeeding during early period, and perform necessary applications during both prenatal and postnatal periods to prevent those.

- Trainings to be given should be cared for being suitable for educational level of the mothers and in the way they can understand.

- In the literature, number of studies which reviewed the effect of satisfaction of mothers from birth on breasfeeding self-sufficiency are quite limited. We can suggest more studies to make on this topic.

\section{Acknowledgment}

Regarding the research and/or authorship of this article, the authors didn't receive any financial

\section{References}

1. Demirci H. İlk gebeliği olan kadınların psikolojik tepkilerinin incelenmesi (Tez). İstanbul Üniversitesi, Doğum ve Kadın Hastalıkları Hemşireliği Anabilim Dalı Yüksek Lisans Tezi; (1996).

2. Taşcı KD. Postpartum kendini değerlendirme ölçeğinin geçerlik ve güvenirlik çalışması (Tez). Dokuz Eylül Üniversitesi, Hemşirelik Ana Bilim Dalı Doğum ve Kadın Hastalıkları Hemşireliği Yüksek Lisans Tezi; (2005).

3. Taşkın L. Doğum ve Kadın Sağlığı Hemşireliği, 5. Baskı, Sistem Ofset Matbaacılık, Ankara, 365-366., (1997).

4. Taşc1 KD, Mete S. "Postpartum Kendini Değerlendirme Ölçeğinin Geçerlik Ve Güvenirlik Çalışması” Atatürk Üniversitesi Hemşirelik Yüksekokulu Dergisi, 10(2): 20-29., (2007).

5. Tunçel EK, Dündar C, Canbaz S, Pekşen P. "Bir üniversite hastanesine başvuran 0-24 aylık çocukların anne sütü ile beslenme durumlarının saptanması" Cumhuriyet Üniversitesi Hemşirelik Yüksekokulu Dergisi, 10(1): 1-6., (2006).

6. Yenal K, Tokat MA, Ozan YD, Çeçe Ö, Abalın FB. “Annelerin emzirme öz-yeterlilik algıları ile emzirme başarıları arasındaki ilişkinin incelenmesi” Hemşirelikte Eğitim ve Araştırma Dergisi, 10(2): 14-19., (2013).

7. Dennis CL. "The Breastfeeding self-efficacy scale: psychometric assessment of the short form" Journal of Obstetric, Gynecologic and Neonatal Nursing, 32(6): 734744.,(2003).

8. Tokat MA. Antenatal dönemde verilen eğitimin annelerin emzirme öz-yeterlilik algısına ve emzirme başarısına etkisi (Tez). Dokuz Eylül Üniversitesi, Doğum ve Kadın Hastalıkları Hemşireliği Doktora Tezi; (2009).

9. Kızılkaya S. Sezaryen ya da normal spontan doğum yapan primiparlarda doğum deneyiminin doğum sonu yaşam kalitesine etkisi (Tez). Marmara Üniversitesi, Doğum ve Kadın Hastalıkları Hemşireliği Anabilim Dalı Yüksek Lisans Tezi; (2013). 